\title{
Human exploitation of seabirds in coastal southern Chile during the mid-Holocene
}

\author{
Explotación humana de aves marinas durante el Holoceno medio en la \\ costa del sur de Chile
}

\author{
ALEJANDRO SIMEONE ${ }^{1,2} \&$ XIMENA NAVARRO \\ ${ }^{1}$ Instituto de Zoología, Universidad Austral de Chile, Casilla 567, Valdivia, Chile \\ ${ }^{2}$ Current address: Institut für Meereskunde an der Universität Kiel, Düsternbrooker Weg 20, D-24105 \\ Kiel, Germany; e-mail: asimeone@ifm.uni-kiel.de \\ ${ }^{3}$ Escuela de Antropología, Universidad Católica de Temuco, Avenida Alemania 0422, \\ Temuco, Chile; e-mail: rayenxi@uct.cl
}

\begin{abstract}
We analyzed a collection of 738 bird bones, representing a minimum of 71 individuals, found in a settlement of huntergatherers from the mid-Holocene, 5,000 years BP, in the coastal locality of Chan Chan, southern Chile. The camp was inhabited for over ca. 500 years, during which time a steady hunting pressure on the local marine resources was exerted, particularly on seabirds. The most abundant taxon (bones/number of individuals) was the red-legged cormorant Phalacrocorax gaimardi (551/44) which was also the prey which provided the highest edible proportion of body mass. Albatrosses Thalassarche cf. melanophris (103/12) and shearwaters Puffinus cf. griseus (20/5) were secondary prey. Cormorants were presumably hunted at their breeding colonies (which are still present in the area) so it is probable that egging also occurred. Because they are pelagic, albatrosses could have been hunted at sea, but the adequate technology for this (boats, hooks) is not apparent in the archaeological record. The bird assemblage obtained in the sample does not qualitatively differ from that of the present, indicating a reasonable stability in species richness from the considered period until the present. The high diversity of coastal resources in Chan Chan was likely important in leading to the, at least seasonal, occupation of these areas by hunter-gatherers and also may have encouraged the development of the adequate technology for the exploitation of these resources.
\end{abstract}

Key words: zooarchaeology, hunter-gatherers, Holocene, seabirds, Phalacrocorax, Chile.

\section{RESUMEN}

Se analizaron 738 restos óseos de aves, correspondientes a un mínimo de 71 individuos, encontrados en un asentamiento de cazadores-recolectores del Holoceno medio, 5.000 años AP, en la localidad costera de Chan Chan, sur de Chile. El campamento fue habitado durante al menos 500 años, tiempo durante el cual se ejerció una presión de caza persistente sobre los recursos marinos locales, particularmente las aves marinas. El taxón más numeroso (restos/ número de individuos) fue el lile Phalacrocorax gaimardi (551/44) que además fue la presa comestible más aprovechable. Albatros Thalassarche cf. melanophris. (103/12) y fardelas Puffinus cf. griseus (20/5) fueron presas secundarias. Los cormoranes fueron presumiblemente cazados en sus colonias reproductivas (las que aún existen en la zona) por lo que es probable que también se hayan consumido los huevos. Por sus hábitos pelágicos, los albatros pudieron haber sido cazados en el mar, aunque la tecnología necesaria para ello (botes, anzuelos) aún no ha sido demostrada en el registro arqueológico. El ensamble avifaunístico de la muestra no difiere cualitativamente del actual, lo que indica una estabilidad en la riqueza de especies desde el período considerado hasta el presente. La gran diversidad de recursos costeros de Chan Chan habría sido importante en la ocupación de estos sectores por grupos de cazadores-recolectores, al menos estacionalmente, lo que además habría estimulado el desarrollo de tecnologías para su explotación.

Palabras clave: zooarqueología, cazadores-recolectores, Holoceno, aves marinas, Phalacrocorax, Chile.

\section{INTRODUCTION}

Anthropogenic deposits of animal bones and other remains in ancient human settlements may provide documentation of the prehistoric abundance, distribution, hunting pressure, and breeding of species in an area, as well as information con- cerning their habitats (e.g., Humphrey et al. 1993). These data may also increase our understanding on the economic and cultural strategies of ancient people, how they exploited their environments and the importance of resources in determining habitation patterns (e.g., Berwick 1975, Lefèvre 1997, Reitz 2001). 
During the early and mid Holocene, the coast of southern Chile and Patagonia was inhabited by groups of hunter-gatherers that actively exploited diverse marine resources including fishes, bivalves, gastropods, seabirds, and marine mammals that provided food and by-products for cultural and economic purposes (Ortiz-Troncoso 1973, Legoupil 1986, Prieto 1988, Lefévre 1989, Mena 1989, Bate 1990, Lanata 1993, Lefèvre 1993, Massonne et al. 1993, Aschero 1994, Lefèvre 1997, Legoupil 1997). The exploitation of these resources implied the development of technologies that allowed their optimal use (Lanata 1993, Navarro \& Pino 1999') and played a major role in allowing human groups to occupy these coastal areas, at least seasonally, along most of the Pacific coast (Lefèvre 1997, Keefer et al. 1998, Sandweiss et al. 1998, Reitz 2001).

The analysis of bird remains from archaeological sites has proved to be useful in indicating that the avifaunal composition of southern Chile and Patagonia has remained reasonably stable over the last 10,000 years and that few taxa have became extinct during this period due to overkill or other human activities (Vuilleumier 1984, Humphrey et al. 1993).

Subfossil collections have also permited complex taxonomic issues to be resolved (e.g., SiegelCausey \& Lefèvre 1989). Remains of diverse marine and coastal birds in middens including albatrosses, penguins, cormorants, gulls and seaducks suggest that these species were exposed to a constant, probably strong, hunting pressure during most of the Holocene (Legoupil 1986, Lefèvre 1989, 1997, Siegel-Causey \& Lefèvre 1989, Lanata 1993).

In this paper we document the bird remains recovered from the archaeological site $\mathrm{CH}-\mathrm{CH} 18$ in the coastal locality of Chan Chan near Valdivia, southern Chile. This human settlement was a semipermanent camp, inhabited by hunter-gatherers organized in family groups over a period of at least 500 years sometime between 5,000 to 5,700 years before present (Navarro \& Pino 1999). The site had a complex spatial and social organization

\footnotetext{
${ }^{1}$ NAVARRO X \& M PINO (1999) Estrategias adaptativas en ambientes costeros del bosque templado lluvioso de la zona mapuche: una reflexión desde el precerámico.

Terceras Jornadas de Arqueología de la Patagonia, Buenos Aires, Argentina: 65-82.

${ }^{2}$ NAVARRO X (2000) Mirada desde la arqueología del paisaje para entender las ocupaciones iniciales de la costa norte de Valdivia (Alepúe, Chan Chan y Pelluco), X región. Decimoquinto Congreso Nacional de Arqueología Chilena, Arica, Chile: 44.
}

that included areas for habitation, a funeral site, cooking, working, and sites where animals were butchered for food, skins, and other uses (Navarro \& Pino 1999, Navarro $2000^{2}$ ). Although remains of invertebrates, fishes and marine mammals have also been found, only the bird remains have been currently adequately identified and quantified. We attempt to use these remains as a basis for infering (a) the importance of birds in the economy of the Chan Chan inhabitants, (b) the extent of the seasonal use of the area, (c) past distribution of certain bird species and (d) human hunting pressure on these resources.

\section{MATERIAL AND METHODS}

\section{Study area}

The archaeological site $\mathrm{CH}-\mathrm{CH} 18$ is located on a partially vegetated sand terrace ca. $10 \mathrm{~m}$ above sea level and $50 \mathrm{~m}$ from the shoreline on an exposed sandy beach in the locality of Chan Chan (39 $\left.30^{\circ} \mathrm{S} ; 7^{\circ} 15^{\circ} \mathrm{W}\right) 50 \mathrm{~km} \mathrm{NW}$ from Valdivia, Chile. The remains were excavated from a matrix formed of sand, abundant calcareous material (sea shells), ash and charcoal. This matrix composition permited good preservation of the remains, particularly hindering decalcification of the bone material (see Berwick 1975).

\section{Methods}

Field expeditions were performed in January 1995 , November 1995, January 1996 and January 1997. Excavations were concentrated in trench Ch-24 (partitioned in ten $1 \times 1 \mathrm{~m}$ grids), where $98 \%$ of bird bones were recovered. The remaining bones were obtained from trench Ch-19. At eight grids within trench Ch-24, seven excavation layers were established: surface, $0-10 \mathrm{~cm}, 10-20 \mathrm{~cm}, 20-30$ $\mathrm{cm}, 30-40 \mathrm{~cm}, 40-50 \mathrm{~cm}$ and $50-60 \mathrm{~cm}$. At Ch-19 surface collection was done at only one grid. Each layer was considered a single independent unit for bone identification and quantification (Humphrey et al. 1993).

Radiocarbon analysis in years before present (years BP) were determined from charcoal at the Beta Analytic Laboratories, California, USA. Resulting dates were as follows: 5,000 \pm 70 years $\mathrm{BP}$ (at $45 \mathrm{~cm}), 5,360 \pm 90$ years BP (at $55 \mathrm{~cm}$ ) and $5,620 \pm 100$ years BP (at $155 \mathrm{~cm}$ ).

Bones were recovered from the sandy substrate with fine brushes, tweezers and dissecting needles. Because bones were extremely fragile after being exposed (due to high humidity), we alternated 
periods of excavation and drying (to the sun and wind). Subsequently, a solution of acetone with liquid glue (commercial name: Uhu Stic) was applied to the bones to harden them. Once completely removed and dried, bones were protected with aluminum paper, put into labeled plastic bags and packed in cardboard boxes for transport.

In the laboratory, avian bones were separated from those of other taxa (e.g., mammals, fishes), cleaned, glued together (only those fractured due to transport and handling), and individually numbered (Berwick 1975). Bones were identified with reference to series of bird skeletons in the collection of the Museo Nacional de Historia Natural (Santiago), as well as material from the collection of the Instituto de Zoología, Universidad Austral de Chile (Valdivia). We also established a reference collection of skeletons from recent specimens. In the particular case of cormorants, we followed the osteological keys (but not the proposed nomenclature) of Siegel-Causey (1988). For bird nomenclature we followed Araya et al. (1995, 1998), except for albatrosses where we used Robertson \& Nunn (1998).

The minimum number of individuals (MNI) was calculated for each taxon as the number of the most abundant diagnostic element (i.e., humerus, ulna, carpometacarpus, coracoid, femur, tibiotarsus, tarsometatarsus) of one side for each excavation level, considering whether proximal and distal fragments overlapped or were of similar sizes and whether right or left elements were of similar sizes (Humphrey et al. 1993, Lemus \& Torres-Mura 1993). Total amounts of bones per layer were weighed using an electronic balance to the nearest $0.1 \mathrm{~g}$. All the analyzed bones are currently deposited at the Museum "Maurice van de Maele", Universidad Austral de Chile, Isla Teja, Valdivia.

\section{RESULTS}

\section{Systematic accounts}

A total of 738 bird bones weighing $741.8 \mathrm{~g}$ was obtained from the trenches Ch-19 and Ch-24. From this sample, 687 bones (93\%) were anatomically identified and assigned to a specific taxon (NISP $=$ number of identified specimens) and represented a minimum of 71 individuals (MNI = minimum number of individuals $)$ of at least seven species from six families (Table 1). Fifty-one bone remains could not be identified. Two seabird taxa, albatrosses and cormorants, dominated the sample both in NISP and MNI (Table 1).

We were able to compare the albatross bones with only one black-browed albatross Thalassarche melanophris skeleton. Although bones coincided in size and shape, the lack of osteological material from other similar-sized species (at least four according to Araya et al. 1998) allowed identification only to the genus level (Thalassarche sp.). The bones utilized in identification are shown in Fig. 1A.

Shearwaters were identified using skeletons of sooty shearwaters Puffinus griseus, and an incomplete skeleton of a pink-footed shearwater $P$. creatopus. As with albatrosses, due to the lack of

TABLE 1

Number of identified specimens (NISP) and minimum number of individuals (MNI, in parenthesis) of bird taxa found at $\mathrm{CH}-\mathrm{CH} 18$

Número de elementos identificados (NISP) y número mínimo de individuos (MNI, entre paréntesis) de taxa de aves encontrados en $\mathrm{CH}-\mathrm{CH} 18$

\begin{tabular}{|c|c|c|c|c|c|c|c|c|c|}
\hline \multirow[t]{2}{*}{ Family } & \multirow[t]{2}{*}{ Genus / species } & \multirow[b]{2}{*}{ Surface } & \multirow[b]{2}{*}{$0-10$} & \multirow[b]{2}{*}{$10-20$} & \multicolumn{2}{|l|}{ Layer } & \multirow[b]{2}{*}{$40-50$} & \multirow[b]{2}{*}{$50-60$} & \multirow[t]{2}{*}{ Total } \\
\hline & & & & & $20-30$ & $30-40$ & & & \\
\hline Diomedeidae & Thalassarche cf. melanophris & $20(4)$ & $2(1)$ & $15(1)$ & $15(2)$ & $36(2)$ & $4(1)$ & $11(1)$ & $103(12)$ \\
\hline \multirow[t]{2}{*}{ Procellariidae } & Puffinus cf. griseus & & $15(2)$ & $2(1)$ & & $3(2)$ & & & $20(5)$ \\
\hline & Fulmarus glacialoides & & & & $1(1)$ & & & & $1(1)$ \\
\hline Phalacrocoracidae* & Phalacrocorax gaimardi & $50(4+3)$ & $61(3)$ & $49(3+1)$ & $178(9+1)$ & $114(9+1)$ & $50(5+1)$ & $49(3+1)$ & $551(36+8)$ \\
\hline Laridae & Larus dominicanus & $2(2)$ & & & $1(1)$ & $1(1)$ & & & $4(4)$ \\
\hline Rallidae & Fulica armillata & & & & & & $1(1)$ & & $1(1)$ \\
\hline Muscicapidae & Turdus falcklandii & & $5(2)$ & $1(1)$ & & & $1(1)$ & & $7(4)$ \\
\hline Undetermined & & 2 & 5 & 15 & 10 & 9 & 7 & 3 & 51 \\
\hline Total & & $74(12)$ & $88(8)$ & $82(6)$ & 205 (14) & $163(15)$ & $63(8)$ & $63(4)$ & $738(71)$ \\
\hline Weight (g) & & 104.7 & 95.9 & 62.6 & 212.7 & 184.8 & 50.3 & 30.8 & 741.8 \\
\hline
\end{tabular}

$*$ MNI: adults + juveniles 
skeletons of other similar-sized shearwaters (at least three according to Araya et al. 1998), we were able to identify specimens only to the genus level (Puffinus sp.). Identification was possible using highly diagnostic bones for this genus including femora, tibiotarsi, tarsometatarsi and humeri.
A southern fulmar Fulmarus glacialoides was identified from one distal fragment of a right humerus. The bone was highly diagnostic for the species, the only of its genus currently occurring in South America (Murphy 1936).
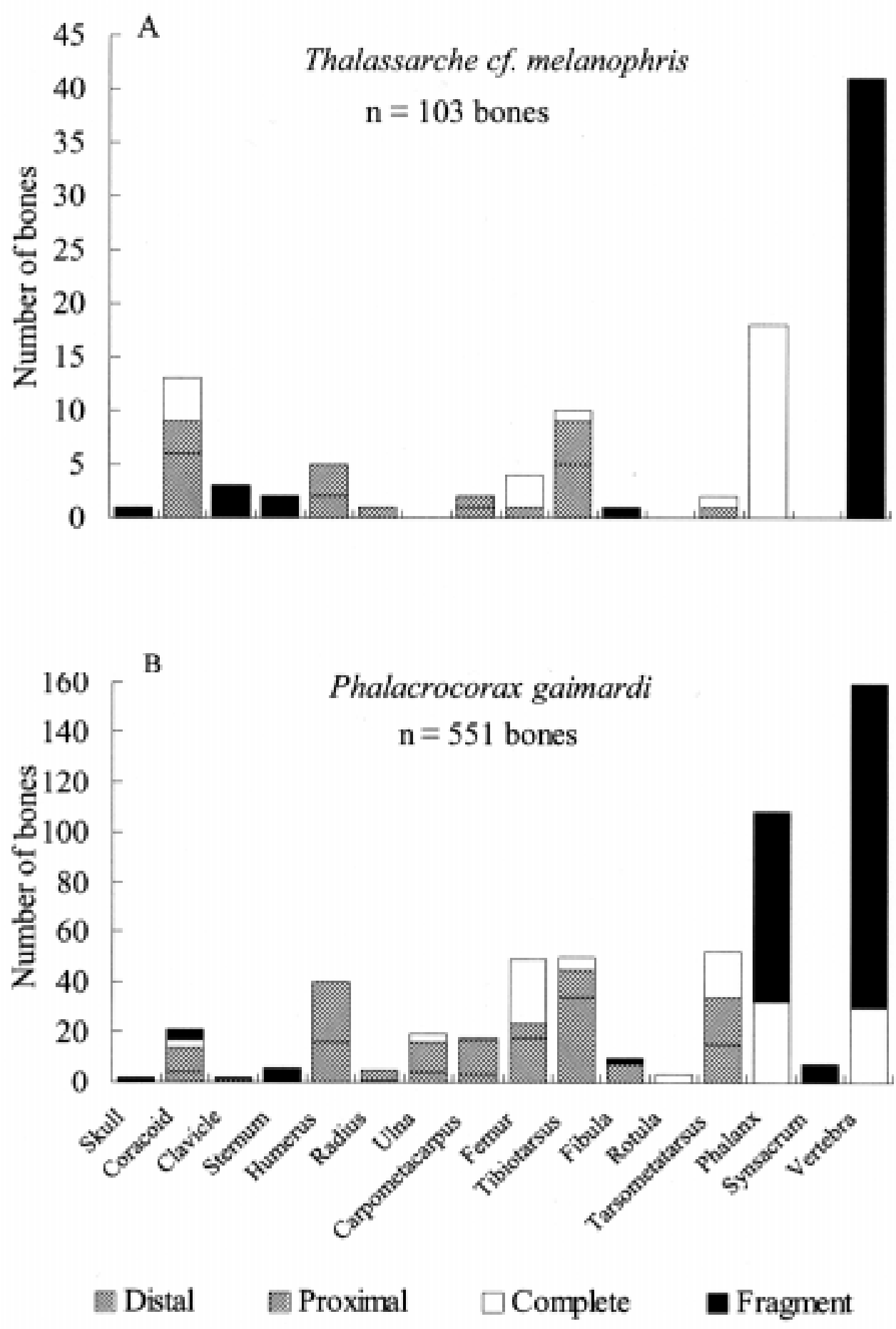

Fig 1: Detail of identified bones for (A) Talassarche cf. melanophris and (B) Phalacrocorax gaimardi. Detalle de huesos identificados para (A) Talassarche cf. melanophris y (B) Phalacrocorax gaimardi. 
Cormorant bones in the sample were compared with skeletons of five of the six species currently reported for Chile (see Araya et al. 1995): blueeyed cormorant $P$. atriceps, olivaceus cormorant $P$. brasilianus, guanay cormorant $P$. bougainvillii, Magellan cormorant $P$. magellanicus and redlegged cormorant $P$. gaimardi. The bones agreed in size and characters only with those of the latter. Main bones utilized in identification are shown in Fig. 1B.

Bones of gulls were compared with specimens of kelp gull Larus dominicanus, dolphin gull $L$. scoresbii, Franklin's gull L. pipixcan, and brownhooded gull L. maculipennis. In both size and characteristics, the bones were readily identified as those of the highly diagnostic kelp gull, the largest species occurring in southern South America (Murphy 1936). Identification was possible based on one distal fragment of a right tibiotarsus, a complete right tibiotarsus and two distal fragments of right femora.

A coot was determined from a proximal fragment of a right humerus. Comparisons were made with skeletons of the similar-sized red-fronted coot Fulica rufifrons and red-gartered coot Fulica armillata. The analyzed bone agreed in size and shape with those of the latter.

A small thrush was identified based on a complete left humerus, two distal fragments of right tibiotarsi, two distal fragments of left tibiotarsi, one distal fragment of a right tarsometatarsus and one proximal fragment of a left femur. Bones were compared with skeletons of the similarsized chiguanco thrush T. chiguanco and austral thrush $T$. falcklandii. The bones agreed in size and form with the latter.

\section{Utilizable body mass of avian prey}

If only muscles and organs are considered as those parts useful for nutritional purposes (see Lefèvre 1989), cormorants were the most profitable of the avian prey, followed by gulls and thrushes (Table 2). Shearwaters were among

\footnotetext{
${ }^{3}$ GAETE N, R SÁNCHEZ \& L VARGAS (1999) Caza, pesca y recolección durante el arcaico en la costa del interfluvio Maule-Itata, Área Extremo Sur Andina, Chile. Primer Seminario de Arqueología Zona Centro Sur de Chile, Concepción, Chile: 7-23

${ }^{4}$ QUIROZ D, M SÁNCHEZ, M VÁSQUEZ, M MASSONNE \& L CONTRERAS (1999) Cazadores "Talcahuenenses" en las costas de Arauco durante el Holoceno Medio. Primer Seminario de Arqueología Zona Centro Sur de Chile, Concepción, Chile: 75-82.
}

\section{TABLE 2}

Utilizable body mass (muscles and organs) in relation to individual body mass of each bird taxon; $\mathrm{BM}=$ body mass, $\mathrm{UBM}=$ utilizable body mass

Masa corporal utilizable (músculos y órganos) en relación a la masa corporal individual de cada taxón de aves; $\mathrm{BM}=$ masa corporal, $\mathrm{UBM}=$ masa corporal utilizable

\begin{tabular}{lccc}
\hline Bird taxon & $\begin{array}{c}\text { BM } \\
(\mathrm{kg})\end{array}$ & $\begin{array}{c}\text { UBM } \\
(\mathrm{kg})\end{array}$ & $\begin{array}{c}\text { UBM/BM } \\
\text { ratio }\end{array}$ \\
\hline Thalassarche cf. melanophris & $3.70^{\mathrm{a}}$ & $1.40^{\mathrm{f}}$ & 0.38 \\
Puffinus cf. griseus & $0.82^{\mathrm{a}}$ & $0.23^{\mathrm{f}}$ & 0.28 \\
Fulmarus glacialoides & $0.73 \mathrm{a}$ & $0.33^{\mathrm{f}}$ & 0.45 \\
Phalacrocorax gaimardi & $1.50^{\mathrm{b}}$ & $1.15 \mathrm{f}$ & 0.77 \\
Larus dominicanus & $1.03^{\mathrm{c}}$ & $0.57 \mathrm{f}$ & 0.55 \\
Fulica armillata & $1.00^{\mathrm{d}}$ & $0.35^{\mathrm{d}}$ & 0.35 \\
Turdus falcklandii & $0.09^{\mathrm{e}}$ & $0.05^{\mathrm{f}}$ & 0.56 \\
\hline
\end{tabular}

Sources: ${ }^{a}$ Warham (1990), ${ }^{b}$ Murphy (1936), ${ }^{\mathrm{c} S c h l a t t e r ~ \& ~}$ Riveros (1997), ${ }^{\mathrm{d}}$ Ruiz (1993), ${ }^{\mathrm{e}} \mathrm{R}$. Schlatter personal communication, fLefèvre (1989)

the least profitable. From the total contribution of utilizable body mass of all avian prey, cormorants represented $70 \%$ and albatrosses 23 $\%$ (Table 3).

\section{Cultural modification of bones}

Six worked bones were found: four of cormorants (2 fibulae, 2 tibiotarsi) and two of albatrosses (1 fibula, 1 ulna). The fibulae and tibiotarsi were finely polished in one of the extremes resembling a needle. Several bones presented traces of burning, both from albatrosses (1 carpometacarpus, 1 humerus) and cormorants (3 vertebrae, 1 tarsometatarsus, 1 carpometacarpus, 5 phalanx, and 1 humerus).

\section{DISCUSSION}

Few coastal archaeological sites in central-south Chile $\left(35^{\circ}\right.$ to $\left.43^{\circ} \mathrm{S}\right)$ present abundant and wellpreserved organic remains (e.g., Aspillaga et al. 1995, Gaete et al. 1999³ Navarro \& Pino 1999, Quiróz et al. 19994). CH-CH 18 thus constitutes a good opportunity to study the composition and distribution of the marine avifauna that inhabited this coastal area as well as the habits of the local hunters 5,000 years BP. 
TABLE 3

Contribution of each taxon to total utilizable body mass (muscles and organs).

Abbreviations as in Table 1 and 2

Contribución de cada taxón al total de masa corporal utilizable (músculos y órganos). Abreviaciones como en Tabla 1 y 2

\begin{tabular}{lccc}
\hline Bird taxon & $\begin{array}{c}\text { UBM } \\
(\mathrm{kg})\end{array}$ & $\begin{array}{c}\text { MNI } \\
\text { Thatassarche cf. melanophris }\end{array}$ & $\begin{array}{c}\text { ToM } \\
(\mathrm{kg})\end{array}$ \\
\hline Puffinus cf. griseus & $1.40^{\mathrm{a}}$ & 12 & 16.80 \\
Fulmarus glacialoides & $0.23^{\mathrm{a}}$ & 5 & 1.15 \\
Phalacrocorax gaimardi & $0.33^{\mathrm{a}}$ & 1 & 0.33 \\
Larus dominicanus & $1.15^{\mathrm{a}}$ & 44 & 50.60 \\
Fulica armillata & $0.57^{\mathrm{a}}$ & 4 & 2.28 \\
Turdus falcklandii & $0.35^{\mathrm{b}}$ & 1 & 0.35 \\
Total & $0.05^{\mathrm{a}}$ & 4 & 0.20 \\
\hline
\end{tabular}

Sources: aLefèvre (1989), bRuiz (1993)

Bones were found associated with cultural remains including stone artifacts, hearths, and shell middens (Navarro \& Pino 1999). Some of these bones were modified for tool making which adds a cultural reason for their aquisition apart from the meat yield (Crockford et al. 1997). This may indicate a transport of the birds to the camp after killing and minimizes the possibility of natural deposition. We presume that these birds were hunted mainly for food, although we cannot rule out their use for other by-products such as feathers and skin.
Compared with other marine vertebrate taxa found at the site, seabirds were the most abundant prey both in NISP and MNI (see Table 1 and 4). This provides evidence that birds may have played an important role in the economy of the Chan Chan inhabitants, as was known for the human groups of Patagonia during the Holocene, which actively hunted penguins, petrels, cormorants, gulls, geese and sea ducks (e.g., Ortiz-Troncoso 1973, 1975, Legoupil 1986, Prieto 1988, Lefèvre 1989, 1997). The presence of fresh-water and terrestrial birds in the sample indicates, however, that hunting also took place to a lesser degree in habitats other than marine: coots are typical inhabitants of fresh-water lakes and marshes (as well as the coypu Myocastor coypus, see Table 4), while thrushes are found in woods, forest edges and prairies (Goodall et al. 1951, Araya et al. 1998).

Red-legged cormorants were the most important prey of the taken birds, both in terms of numbers (see Table 1) and the profitability of body mass (see Table 2), and thus may have constituted an important source of animal protein, quite apart from providing bones for the manufacture of tools. The matching of radiocarbon datings and presence in the sample proves that they were hunted for at least 360 years. The presence of juveniles (still flightless) indicates that hunting took place at the colonies and that these were already established in the area at least 5,000 years BP. Today, the red-legged is the only cormorant species nesting in the area, in colonies at coastal cliffs only $1 \mathrm{~km}$ away from the excavated trenches (personal observations). It seems thus, that this species was a very accessible prey

TABLE 4

Other vertebrate taxa found at $\mathrm{CH}-\mathrm{CH} 18$. Abbreviations as in Table 1

Otros taxa de vertebrados encontrados en $\mathrm{CH}-\mathrm{CH}$ 18. Abreviaciones como en Tabla 1

\begin{tabular}{llcc}
\hline Class & Genus / species & NISP & MNI \\
\hline \multirow{2}{*}{ Pisces* } & Sicyases sanguineus Müller \& Troschel 1843 & 440 & ND \\
& Thyrsites atun (Euphrasen 1791) & 100 & ND \\
& Cilus gilberti (Abbott 1899) & 60 & ND \\
& Sebastes capensis (Gmelin 1788) & 25 & ND \\
& Other & 100 & ND \\
& Total & 725 & 1 \\
Myocastor coypus (Molina 1782) & 8 & 2 \\
& Undetermined Rodentia & 6 & 1 \\
& Undetermined Cetacea & 2 & 1 \\
& Arctocephalus sp. & 8 & 3 \\
& Otaria byronia (De Blainville 1820) & 54 & 8 \\
\hline
\end{tabular}

ND = not determined, $(*)$ determined by J. Yáñez (unpublished report), $\left.{ }^{* *}\right)$ determined by D. Jackson (unpublished report) 
for the Chan Chan hunters and probably had a high local past abundance.

Data from other midden deposits indicate that several Phalacrocorax cormorants were actively hunted along the Pacific coast at least since the late Pleistocene, with records ranging from southern Perú (Keefer et al. 1998) to Fuego-Patagonia (Ortíz-Troncoso 1973, Siegel-Causey \& Lefèvre 1989, Lanata 1993, Lefèvre 1997) and even locations in the Atlantic (E. Frere personal communication). In these areas, birds were caught with baited hooks at sea or hunted at night with clubs and torches at their resting sites (Bird 1945 quoted by Lefèvre 1989, Cooper 1988).

Because of their size, albatrosses constituted a major bird prey, although the body mass that the Chan Chan hunters were able to use for consumption was comparatively low (see Table 2). The bones of these birds also provided material for tools. Hunting of albatrosses would have be easier at the nesting areas due to their limited mobility on land (Warham 1990), but this seems unlikely because the nearest contemporary colonies (e.g., of T. melanophris) are on Diego de Almagro Island $\left(51^{\circ} \mathrm{S}\right)$, ca. $1,300 \mathrm{~km}$ south of Chan Chan (Clark et al. 1984). Nevertheless, if hunting took place at breeding sites, this would imply a considerable shift in the breeding range of albatrosses over the past 5,000 years (although viable, this idea requires further research). Conversely, as albatrosses are pelagic (Warham 1990) it is also likely that hunting took place at sea, as has been reported for several groups of hunters (e.g., Kodiac islanders in Alaska, Maori in New Zealand, Tristan da Cunha islanders) using harpoons and baited bone hooks from boats (Elliott 1957, Warham 1990, Anderson 1996). While these methods seem feasible, none of the mentioned artifacts has yet been found. Although least probable, it is also possible that some stranded birds were collected from the beach.

The most likely shearwater species to be present in our sample, $P$. griseus, is a transequatorial migrant in the Pacific Ocean and reaches maximum numbers in Chilean waters between October and November (Harrison 1988). Red-legged cormorants raise chicks mainly between October and January (Goodall et al. 1951). Both cases therefore, would suggest that the camp was inhabited at least during spring and summer, although occupation during the rest of the the year cannot be precluded.

Bird eggs may have been another possible source of food. If cormorants were hunted at their breeding grounds as we believe, it is highly probable that egging, a work mostly performed by children (Hilger 1957), also occurred.
Together with cormorants (Phalacrocorax) and steamer ducks (Tachyeres), penguins were common prey for patagonian hunters (e.g., Legoupil 1986, Prieto 1988, Lefèvre 1989, Lanata 1993), but absent in our sample. These flightless birds were easy to catch, particularly at their colonies, and may have provided a reasonable meat yield (40 \% utilizable body mass; Lefèvre 1989). Currently, reduced groups of roosting and moulting Magellanic S. magellanicus and Humboldt penguins $S$. humboldti occur in the area only at Maiquillahue islet, ca $15 \mathrm{~km}$ north of Chan Chan (J. Ruiz and R.P. Schlatter personal communication). If penguins were as uncommon and localized as today, they were probably not an attractive resource for the Chan Chan people, who may have mostly concentrated their hunting effort in the nearby and accessible cormorant colonies.

No extinct species were found in the sample and no range extensions were demonstrated, indicating a similar bird assemblage of the sample to that found in the area today. This agrees with previous works in that bird assemblages of southern South America have changed little during the Holocene, both at the genus and species level, (e.g., Vuilleumier 1984, Humphrey et al. 1993). Redlegged cormorants, however, suffered a prolonged prehistoric hunting pressure, not only locally but over a considerable geographic range (see above). Currently, although this species remains widespread, it is nowhere abundant and populations have declined mainly due to egg-collecting (Birdlife International 2000). Finally, the stability in the seabird assemblage may also suggest that oceanographic conditions have remained reasonably stable during the period in question. Archaeozoological (e.g., Reitz 2001), sedimentological and paleoecological data (e.g., Bennett et al. 2000) suggest that modern oceanographic conditions in the south Pacific coast established in the early and mid-Holocene and have have changed little since then.

It should be considered that our interpretations are based on samples modified by physical (erosion by wind, rain, and sea) and biological factors (bacterial decomposition, action of rodents) since they were originally deposited, and the size as well as the composition of the deposits may have changed (Lanata 1993, Davis 1997). Additionally, the nutritional, social and religious value that the Chan Chan hunters 5,000 years BP gave to the resources also contributed to the formation of the present sample and thus may affect our interpretations. Comparisons and reconstructions of ancient faunas and human life styles must consider these sources of variation. 
The human groups of Chan Chan during the mid-Holocene relied almost exclusively on marine resources while resident on the coast and these may have played a major role in attracting people to habitate the area, as has been the case in other sites along the Pacific coast (e.g., Reitz 2001). The associated cultural material also indicates a technology designed to have access to these resources (Navarro \& Pino 1999) which suggests a reasonable knowledge of the coast and its resources. The acquisition of some fishes, albatrosses and shearwaters even suggests that these people may have penetrated onto the sea, although adequate technology for such an undertaking has not yet been found. Research of coastal areas occupied during the Holocene in centralsouth Chile is increasing (Aspillaga et al. 1995, Gaete et al. 1999, Navarro \& Pino 1999, Quiróz et al. 1999, Navarro 2000) and archeofaunistic deposits are providing valuable information on the diet and resource exploitation strategies of the ancient local inhabitants, thus improving our understanding of the regional human pre-history and ancient faunas.

\section{ACKNOWLEDGMENTS}

Marina Lemus and J.C. Torres-Mura (Museo Nacional de Historia Natural, Santiago) and Roberto P. Schlatter (Instituto de Zoología, Universidad Austral de Chile, Valdivia) aid in bone identification and graetly facilitated access to the skeleton collections at their institutions. E. Frere, J. Ruiz and R. P. Schlatter kindly provided their unpublished data and observations. Comments of M. Thiel, R. Schlatter, G. Luna-Jorquera, R. P. Wilson, C. Lefèvre and an anonymous referee greatly improved the manuscript. Financial support was provided by FONDECYT grant 1950704 to X. Navarro. At the time this paper was written, the first author was holding a scholarship of the German Academic Exchange Service (DAAD). We thank all of them very much.

\section{LITERATURE CITED}

ANDERSON A (1996) Origins of Procellariidae hunting in the southwest Pacific. International Journal of Osteoarchaeology 6: 403-410.

ARAYA B, M BERNAL, RP SCHLATTER \& M SALLABERRY (1995) Lista patrón de las aves chilenas. Tercera edición. Editorial Universitaria, Santiago, Chile. 35 pp.

ARAYA B, G MILLIE \& M BERNAL (1998) Guía de campo de las aves de Chile. Octava edición. Editorial Universitaria, Santiago, Chile. 406 pp.
ASCHERO C (1994) Reflexiones desde el Arcaico tardío (6000-3000 AP). Rumitacana (Argentina) 1: 13-40.

ASPILLAGA E, C OCAMPO, JC OLIVARES, B ARENSBURG \& J MEYER (1995) Una visita a los canoeros de Quetalmahue. Museos (Chile) 20: 18-20.

BATE LF (1990) Culturas y modos de vida de los cazadores recolectores en el poblamiento de América del Sur. Revista de Arqueología Americana (México) 2: 89-153.

BENNETT KD, SG HABERLE, SH LUMLEY (2000) The last glacial-holocene transition in southern Chile. Science 290: 325-327

BERWICK DE (1975) Valoración del análisis sistemático de los restos de fauna en sitios arqueológicos. Chungará (Chile) 5: 125-140.

BIRDLIFE INTERNATIONAL (2000) Threatened birds of the world. Lynx Edicions and Birdlife International, Barcelona, Spain. 852 pp.

CLARK GS, AJ GOODWIN \& AP VON MEYER (1984) Extension of the known range of some seabirds on the coast of southern Chile. Notornis 31: 320-334.

COOPER J (1988) Los Chonos. Chiloé (Chile) 9: 19-28.

CROCKFORD S, G FREDERICK, R WIGEN (1997) A humerus story: albatross element distribution from two northwest coast sites, North America. International Journal of Osteoarchaeology 7: 287291

DAVIS PG (1997) The bioerosion of bird bones. International Journal of Osteoarchaeology 7: 388401

ELLIOTT HFI (1957) A contribution to the ornithology of the Tristan da Cunha group. Ibis 99: 545-586.

GOODALL JD, AW JOHNSON \& RA PHILIPPI (1951) Las aves de Chile, su conocimiento y sus costumbres. Vol I. Platt Establecimientos Gráficos, Buenos Aires, Argentina. $441 \mathrm{pp}$.

HARRISON P (1988) Seabirds, an identification guide. Revised edition. Christopher Helm, London, United Kingdom. 448 pp.

HILGER I (1957) Araucanian child life and its cultural background. Smithsonian Miscellaneous Collections 133: 1-406.

HUMPHREY PS, JE PÈFAUR \& PC RASMUSSEN (1993) Avifauna of three Holocene cave deposits in southern Chile. Occasional Papers of the Museum of National History, University of Kansas, Lawrence 154: 1-37.

KEEFER DK, SD DEFRANCE, ME MOSELEY, JB RICHARDSON III, DS SATTERLEE, A DAY-LEWIS (1998) Early maritime economy and El Niño events at Quebrada Tacahuay, Perú. Science 281: 1833-1835.

LANATA JL (1993) Estados alterados: procesos de formación y conjuntos faunísticos en Rancho Donata, Tierra del Fuego. In: Lanata JL (ed) Explotación de recursos faunísticos en sistemas adaptativos americanos. Arqueología Contemporánea (Argentina) 4: 163 176.

LEFÈVRE C (1989) Les Oiseaux. In: Legoupil D (ed) Ethno-Archéologie dans les Archipels de Patagonie: les nomades marins de Punta Baja: 99-113. Editions Recherche sur les Civilisations, Paris, France.

LEFÈVRE C (1993) Las aves en los yacimientos del archipiélago del Cabo de Hornos y del Seno Grandi. Anales del Instituto de la Patagonia, Serie Ciencias Sociales (Chile) 22: 123-136. 
LEFÈVRE C (1997) Seabird fowling in southern Patagonia: a contribution to understanding the nomadic round of the Canoeros indians. International Journal of Osteoarchaeology 7: 260-270.

LEGOUPIL D (1986) Los indios de los archipiélagos de la Patagonia, un caso de adaptación a un ambiente adverso. Anales del Instituto de la Patagonia, Serie Ciencias Sociales (Chile) 16: 45-52.

LEGOUPIL D (1997) Bahía Colorada. Les premiers chasseurs des mammifères marins de Patagonia australe. Editions Recherche sur les Civilisations, Paris, France. 235 pp.

LEMUS M \& JC TORRES-MURA (1993) Métodos de análisis de los vertebrados presentes en sitios arqueológicos de Chile central. Museos (Chile)16: 6-9.

MASSONNE M, D JACKSON \& A PRIETO (1993) Perspectiva arqueológica de los Selk'nam. Editorial Universitaria, Santiago, Chile. 170 pp.

MENA LF (1989) Cazadores-recolectores y arqueología: problemas y proyecciones teóricas. Boletín de Antropología Americana (México) 19: 30-47.

MURPHY RC (1936) Oceanic birds of South America. Vols I and II. American Museum of Natural History, New York, New York. 1245 pp.

ORTIZ-TRONCOSO O (1973) Aspectos arqueológicos de la Península de Brunswick (Patagonia Austral). Anales del Instituto de la Patagonia (Chile) 4: 109-129.

ORTIZ-TRONCOSO O (1975) Los yacimientos de Punta Santa Ana y Bahía Buena (Patagonia Austral): excavaciones y fechados radiocarbónicos. Anales del Instituto de la Patagonia (Chile) 6: 93-122.

PRIETO A (1988) Cazadores-recolectores del itsmo de Brunswick. Anales del Instituto de la Patagonia, Serie Ciencias Sociales (Chile) 18: 113-131.

Associate Editor: P. Ojeda

Received August 20, 2001; accepted March 15, 2002
REITZ EJ (2001) Fishing in Perú between 10,000 and 3,750 BP. International Journal of Osteoarchaeology 11: $163-171$.

ROBERTSON CJR \& GB NUNN (1998) Towards a new taxonomy for albatrosses. In: Robertson G \& R Gales (eds) Albatros biology and conservation: 13-19. Surrey Beatty and Sons, Chipping Norton, Australia.

RUIZ J (1993) Estudio ecológico en tres especies de taguas residentes en el santuario de la naturaleza del río Cruces. Tesis de grado, Facultad de Ciencias Veterinarias, Universidad Austral de Chile, Valdivia, Chile. 62 pp.

SANDWEISS DH, H MCINNIS, RL BURGER, A CANO, B OJEDA, R PAREDES, MC SANDWEISS \& MD GLASCOCK (1998) Quebrada Jaguay: early South American maritime adaptations. Science 281: 18301832.

SCHLATTER RP \& GM RIVEROS (1997) Historia natural del Archipiélago Diego Ramírez, Chile. Serie Científica del Instituto Atártico Chileno (Chile) 47: 87-112.

SIEGEL-CAUSEY D (1988) Phylogeny of the Phalacrocoracidae. Condor 90: 885-905.

SIEGEL-CAUSEY D \& C LEFÈVRE (1989) Holocene records of the Antarctic shag (Phalacrocorax [Notocarbo] bransfieldensis) in Fuegian waters. Condor 91: 408-415.

VUILLEUMIER F (1984) Faunal turnover and development of fossil avifaunas in South America. Evolution 38: 1384-1396.

WARHAM J (1990) The petrels, their ecology and breeding systems. Academic Press, London, United Kingdom. $440 \mathrm{pp}$. 